Revista de Investigación

Año 13.

Académica sin Frontera

Núm. 33

ISSN: 2007-8870

https://revistainvestigacionacademicasinfrontera.unison.mx/index.php/RDIASF

Recibido el 14 de abril de 2020. Dictaminado mediante arbitraje favorablemente 9 de julio de 2020

\title{
Specification of a local entrepreneurship model
}

\section{Alejandra Velázquez-Orozco https://orcid.org/0000-0003-4055-5679 \\ Laura García Espinoza https://orcid.org/0000-0002-2372-4170 \\ Manuel Zainos Hernández https://orcid.org/0000-0003-2162-4253 \\ Cruz García Lirios https://orcid.org/0000-0002-9364-6796}

\begin{abstract}
Background. The literature local venture out; 1 ) I to migration of talent from universities and emergent, stay in universities and developed talents return to his alma mater; 2) acculturation, multiculturalism and interculturality as management systems for the expulsion and reception of migrants; 3 ) the adaptation of migrant workers and the assimilation and selection of talents, as well as the identity in both; 4) the inexorability between community worker entrepreneurship and academic talent entrepreneurship.

Objective. Specify a model of local entrepreneurship based on a review and discussion of theoretical, conceptual and empirical frameworks related to the migration of workers and talents.
\end{abstract}

Method. A documentary study was conducted with a selection of indexed sources during the period from 2010 to 2019 in repositories in Latin America.

Results. The model specified included after hypothesis of correlational trajectories between the assimilation, selectivity and identity variables reviewed in the state of knowledge.

Discussion. From the approaches of acculturation, multiculturalism and interculturality, the inclusion of explanatory variables of equitable relations between economic, political and social actors is noted. 
Año 13.

Revista de Investigación

Núm. 33

Académica sin Frontera

https://revistainvestigacionacademicasinfrontera.unison.mx/index.php/RDIASF

Recibido el 14 de abril de 2020. Dictaminado mediante arbitraje favorablemente 9 de julio de 2020

Conclusion. The specification of the model can only be checked if it is possible to observe inter-culturalism in the public policies of micro-financing of entrepreneurial projects for local development.

Keywords -Local Development, social entrepreneurship, acculturation, multiculturalism, interculturality

\section{Introduction}

The objective of the present work is to specify a model for the study of transformational leaderships, considering the migratory flows of talents that return to their place of origin with capacities and resources that encourage endogenous development.

Studies concerning the establishment of an agenda, the formation of human capital, the migration of academic talents and local development warn; 1) the influence of the quality of life in the EU and the EU disseminated in the media on vocational training; 2) the establishment of an agenda in education, health and employment with emphasis on opportunities and job skills; 3) the crossing, stay and return of academic talents to state universities (Carreón, 2013).

Based on the state of knowledge, the present work specified a model for the study of the transformational leadership of ex-fellows in local economies. An exploratory study was conducted with a non-probabilistic selection of indexed sources. The information was processed in content analysis matrices to select the variables reported in the state of knowledge. The logical trajectories that explained the dependency relationships between the variables reported in the state of the art were elaborated. 
"Fl wher íle mis hijos

Año 13.

Núm. 33

Académica sin Frontera

ISSN: 2007-8870

Recibido el 14 de abril de 2020. Dictaminado mediante arbitraje favorablemente 9 de julio de 2020

\section{The migration of talents from Mexico to the EU and the EU}

The combination of formation and formation of human capital refers to a social care process in which the welfare state or neoliberal implements expulsion, reception or repatriation policies in order to stabilize the relationship between demands and resources. In this sense, migration is considered a management instrument, since it implies the emergence of strategies that inhibit or facilitate migratory flows based on foreign direct investment (FDI).

In this way, it is known that in the countries of greatest expulsion (China, India, Mexico and Brazil), migratory flows are due to FDI captured in the productive sectors, mainly manufactures of these emerging economies with respect to the growth or crisis of the developed countries, however in the case of Mexico, the migratory flow to the United States was largely due to social rather than economic capital flows (Aguilar et al., 2016).

During the periods of greatest growth in the US, migratory flows intensified, but in the period of recession and economic crisis in which employment was cut, the migratory flows of Mexico and Central America remained slightly lower with respect to the boom period, but the anti-migrant policies that criminalized the border crossing, failed to bring down family networks that remained constant during periods of crisis (García et al., 2013) .

Thus, migratory flows are not only an economic phenomenon, not even a political one, but also a social and more punctual one, that is because migratory or anti-migrant policies intensified in a period of economic crisis, when a budget cuts to containment strategies.

However, the adaptation, assimilation or selectivity of the migrant's journey and stay only explain the migratory flows, but they ignore family networks that have 
Revista de Investigación

Núm. 33

Académica sin Frontera

https://revistainvestigacionacademicasinfrontera.unison.mx/index.php/RDIASF

Recibido el 14 de abril de 2020. Dictaminado mediante arbitraje favorablemente 9 de julio de 2020

been studied by the TS as a welfare, transcultural or labor phenomenon. It is known that employment determines the quality of life, but it is unknown if family networks transform the quality of life into social or subjective well-being (Carreón, 2016).

Therefore, the identity hypothesis makes explicit the relationship between migrants and residents within the framework of financial flows and economic crises. It is the identity that explains the labor networks and the type of employment that would anticipate the health of migrants.

\section{Theory of migration flows}

The theory of migratory flows warns three cultural relations between migrant communities and native towns. It is about acculturation that consists in adapting and assimilating the values and norms of a dominant culture with respect to migrant cultures. This is the case of workers who do not always learn a language, but contribute their labor to the developed economy.

In the case of migrant talents, a human capital with high specialization of knowledge, acculturation does not explain their stay and return to their home university (García, Valdés and Sandoval, 2016).

The multiculturalism approach highlights talent selection as a consequence of developed economies by incorporating competitive management systems that only the most capable can meet the quality of the processes and products required. This is the case of developed countries with high specialization and production of science and technology (García, Morales and Carreón, 2013).

Criticisms of the multicultural approach lie in the exclusion of talents in the political representation of migrants, since government structures and systems do not contemplate talent selectivity for minority governance. 
"Fl wher íte mis hijos

Año 13.

Núm. 33
Revista de Investigación

Académica sin Frontera

ISSN: 2007-8870

https://revistainvestigacionacademicasinfrontera.unison.mx/index.php/RDIASF

Recibido el 14 de abril de 2020. Dictaminado mediante arbitraje favorablemente 9 de julio de 2020

It will be the intercultural approach that, through representative management, will propose the discussion, agreement and co-responsibility between dominant cultures and migrant cultures. This is the case of governments that disseminate equity and co-responsibility in their institutions (García et al., 2015).

The intercultural approach does not warn about the identity processes that link the migrant with their community of origin. In the case of return, none of the three approaches anticipates possible management and social entrepreneurship scenarios based on the differences between migrant workers and ex-fellows.

The differences between resident and ex-migrant migrants who returned with respect to the assumptions of 1) assimilation, 2) adaptation , 3) selectivity and 4) identity in the United States have been developed following Karl Popper's contrasting principles which argues that a theory it is a provisional explanation of phenomenal reality.

The Theory of Labor Adaptation, the one that raises a difference between the labor conditions of the expelling country with respect to the receiving country, only explained the departure and arrival of migrants, but the reasons why they went to spaces inhabited by other migrants, even from their own places of origin, were not fully explained, since labor adaptation implies a pragmatic process of choice that contradicts peripheral decision making to costs and benefits (Rivera et al., 2015) .

The Theory of Migration Assimilation by stating that the countries that expel or guarantee a quality of life and social welfare of their workers, determine an excessive supply of labor in the receiving countries. In this scenario, migration is a catalyst that tries to balance labor supply and demand, but in the case of migrants and ex-migrants, the difference was due to the relations between family and friends, social capital defined access to resources and supports (García et al., 2016). 
Revista de Investigación

Núm. 33

Académica sin Frontera

https://revistainvestigacionacademicasinfrontera.unison.mx/index.php/RDIASF

Recibido el 14 de abril de 2020. Dictaminado mediante arbitraje favorablemente 9 de julio de 2020

The Theory of Migratory Selectivity argues that only a small group of talents will be willing to migrate in order to obtain a better job and income that allows them to develop their abilities. In this conceptual logic, migration is a process that goes from freedoms to responsibilities in which the opportunities offered by the State for its management will be determinants of individual capacities. However, migrants, having a high level of education and especially having learned an innovative process among their group, developed an identity that rather explains their differences (Carreón et al., 2014).

The Theory of Migratory Identity when considering that the differences between sending and receiving countries lie in the propensity for the future, observes asymmetries among their civil groups that not only develop entrepreneurial networks, but civic virtues that differentiate them from other sectors. In this way, the migratory identity is a process that goes from the opportunities promoted by business promotion policies to citizen responsibilities that would explain the remittances, although it is a complex process in which the political and social actors are immersed (García et al., 2015).

\section{Specification of the local entrepreneurship model}

Under that former grantees talents have -Skills and knowledge of language rights, competencies-, then only the assumptions of assimilation, selectivity and identity were considered

In other words, in the process of travel, stay and return former grantees of Conacyt seem to have assimilated a dominant culture, to focus their expectations on the opportunities for education and employment that broadcast media in favor of a dominant culture in EU and EU, which is associated with the selective processes 
Revista de Investigación

Núm. 33

Académica sin Frontera

https://revistainvestigacionacademicasinfrontera.unison.mx/index.php/RDIASF

Recibido el 14 de abril de 2020. Dictaminado mediante arbitraje favorablemente 9 de julio de 2020

inherent in migratory flows such as passport or visa procedures, language, knowledge and prestige networks that entails being a scholar and student, but the ex-grantees are talents that stood out for their abilities, even though they had to leave their place of origin and family, now with knowledge, resources and prestige return to live their last period of life with their primary group and contribute to local development.

\section{Discussion}

The contribution of this work to the state of knowledge lies in the specification of a model in which three hypotheses of correlation trajectories between the processes and migratory flows reviewed in the literature are included.

However, the specified model does not include variables related to interculturalism, defined as a system of participation, debate, agreements and coresponsibilities that are reflected in the equitable distribution of political and legal actors from migrant cultures with respect to a dominant culture.

Aguilar et al., (2016) points out that interculturalism should be present in Higher Education Institutions and be reflected in vocational training, but since they are subject to a centralized and unilateral administration, the assimilation and selectivity of migrants is more likely than dialogue.

In relation to the return of migrants to their home universities, it is possible to infer that they assimilated and exceeded academic selectivity, but were unable to participate in the establishment of an academic instance that involved an exchange between the expelling university and the talent recipient.

Carreón (2013) observes in the migratory flows of workers the return as part of a life cycle in which, at the end of the boom and recognition period, day laborers 
Revista de Investigación

Núm. 33

Académica sin Frontera

https://revistainvestigacionacademicasinfrontera.unison.mx/index.php/RDIASF

Recibido el 14 de abril de 2020. Dictaminado mediante arbitraje favorablemente 9 de julio de 2020

return to their place of origin to take care of their built heritage and inherit it to your children or relatives.

In contrast, ex-grantee talents returning to the country developed a discourse on the governance of the common resources of their specialized and up-to-date training in the EU and the EU, but their propensity for entrepreneurship is reduced to its minimum expression by not having the structural and administrative facilities to carry out your business project or knowledge production (Carreón, Hernández and García, 2016).

The governance of local development would not only allow the systematic repatriation of ex-fellows, but also generate an equitable exchange of talents between the sending countries and the receiving economies, although entrepreneurship arises from a shortage of opportunities and exclusive public policies (García et al., 2014).

However, García, Morales and Carreón (2013) warn that civil society sectors excluded from micro-financing are organized around cooperation and solidarity, disconnected from the projects of companies and institutions, public and private. It is a process that reduces social suffering and once this objective is achieved, it is disseminated in family businesses that, when not managed under a management system, disappear in the first three years of life (García, Valdés and Sandoval, 2016).

If the quality of life and entrepreneurship is disseminated in the media as a heritage of transnational companies and prestigious institutions, then the communities that expel and receive workers and ex-fellows face the challenge of establishing dialogue channels that allow alliances strategies among the actors (Mejía, García and Carreón, 2014). 
Año 13.

Revista de Investigación

Núm. 33

Académica sin Frontera

https://revistainvestigacionacademicasinfrontera.unison.mx/index.php/RDIASF

Recibido el 14 de abril de 2020. Dictaminado mediante arbitraje favorablemente 9 de julio de 2020

Communities that accumulate greater distrust in their federal and local governments, not only increase the exclusion of social entrepreneurship with respect to academic entrepreneurship, but also generate a separation between actors who returned with resources and capabilities, but were limited by local culture (Rivera et al., 2015)

Lines of research concerning interculturalism in relation to acculturation and multiculturalism would reveal an integral model in which the local development of communities that expel workers and ex-fellows would be based on a governance of resources and capacities.

\section{References}

Aguilar, J., Bautista, M., García, C., Hernández, G., Sandoval, F., Pérez, G. and Valdés, O. (2016). Reliability and validity of an instrument that measures educational institutionalism in a public university of the State of Mexico. Borderless, 9 (22), 1-16

Carreón, J. (2013). Speeches about labor migration. The return and social reintegration from the group identity in Xilitla, micro-region of the Huasteca potosina (Mexico). In L. Cano (coord.). Poverty and social inequality challenges for the configuration of social policy. (pp. 153-174). Mexico: UNAM-ENTS.

Carreón, J. (2016). Human development: Governance, Local Development and social entrepreneurship. Mexico: UNAM-ENTS

Carreón, J., Hernández, J. and García, C. (2016). Contrast of a sustainable postmaterialism model. Journal of Psychology, 1 (1), 1-27

Carreón, J., Hernández, J., Morales, M., García, C., García, E. and Rosas, F. (2014). Local entrepreneurship for sustainable human development. Margin, 74, 1- 
Año 13.

Revista de Investigación

Núm. 33

Académica sin Frontera

https://revistainvestigacionacademicasinfrontera.unison.mx/index.php/RDIASF

Recibido el 14 de abril de 2020. Dictaminado mediante arbitraje favorablemente 9 de julio de 2020

García, C., Morales, M. and Carreón, J. (2013). Local Development, water vulnerability, job insecurity, migratory intensity and resilient identity. Kairos, 17 (32), 1-17

García, C., Valdés, O. and Sandoval, F. (2016). Algorithmic and neguentropic complexity in models that explain social suffering in Mexico City. Margin, 81, 1-6

García, E., García, C., Rosas, F., Castillo, M., Carreón, J., Hernández, J. and Rivera, B. (2015). Empirical test of a quality of life model. Civilize, 15 (28), 181-196

Mejía, S., García, C. and Carreón, J. (2014). Roles and positioning of Social Work around Eurocentric power and influence. Margin, 75, 1-8

Rivera, B., García, C., García, E., Rosas, F., Limón, G., Carreón, J., Hernández, J. and Morales, M. (2015). Contrast of a model of political distrust. Psychological Science, 7 (1), 1-8 
Año 13.

Revista de Investigación

Núm. 33

Académica sin Frontera

https://revistainvestigacionacademicasinfrontera.unison.mx/index.php/RDIASF

Recibido el 14 de abril de 2020. Dictaminado mediante arbitraje favorablemente 9 de julio de 2020

\section{Directorio Institucional}

Dr. Enrique Fernando Velázquez Contreras

Rector

Dr. Ramón Enrique Robles Zepeda

Secretario General Académico

Dra. Rosa María Montesinos Cisneros

Secretaria General Administrativa

Dr. Rodolfo Basurto Álvarez

Director de Vinculación y Difusión

Dra. Adriana Leticia Navarro Verdugo

Vicerrectora de la Unidad Regional Sur

Dr. Ernesto Clark Valenzuela

Director de la División de Ciencias Económicas y Sociales

Dr. Francisco Espinoza Morales

Secretario de la División de Ciencias Económico y Sociales

Dra. Leticia María González Velásquez

Jefe del Departamento de Ciencias Económico Administrativas

Dra. Lidia Amalia Zallas Esquer

Jefe de Departamento de Ciencias Sociales 
Año 13.

Revista de Investigación

Núm. 33

Académica sin Frontera

https://revistainvestigacionacademicasinfrontera.unison.mx/index.php/RDIASF

Recibido el 14 de abril de 2020. Dictaminado mediante arbitraje favorablemente 9 de julio de 2020

\section{Comité Directivo}

\section{Editor Responsable}

Dr. Francisco Espinoza Morales

\section{Directora}

Dra. Leticia María González Velásquez

\section{Subdirector}

Dr. Javier Carreón Guillen

\section{Editor Científico}

Dr. Cruz García Lirios

\section{Master Gráfico}

M.T.I. Francisco Alan Espinoza Zallas

Nos complace anunciar que su diario, "Academic Research Journal Withoutborders" (ISSN/EISSN 2007-8870) fue evaluado positivamente en la indexación Citefactor, ahora la página de la revista está disponible en línea, en caso de cualquier problema. Journals Master | International Innovative Journal Impact Factor (IIJIF)

Red Latinoamericana de revistas Académicas en Ciencias Sociales y Humanidades

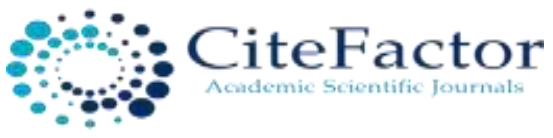

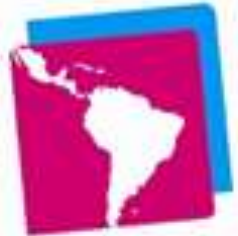

LatinREV

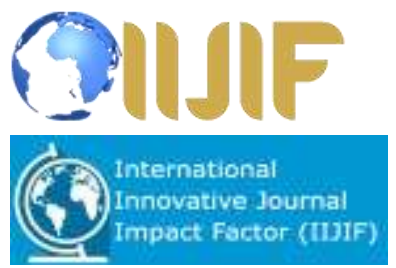


Año 13.

Revista de Investigación

Núm. 33

Académica sin Frontera

https://revistainvestigacionacademicasinfrontera.unison.mx/index.php/RDIASF

Recibido el 14 de abril de 2020. Dictaminado mediante arbitraje favorablemente 9 de julio de 2020

\section{Comité editorial}

Dra. Angélica María Rascón Larios

Universidad de Sonora. México

Dra. María del Rosario Molina González

Universidad de Sonora

Dra. Francisca Elena Rochin Wong

Universidad de Sonora. México

Dra. Lidia Amalia Zallas Esquer

Universidad de Sonora. México

Dra. Beatriz Llamas Arechiga

Universidad de Sonora. México

Dr. Rogelio Barba Álvarez

Universidad de Guadalajara. México

Dra. Rosa María Rincón Ornelas

Universidad de Sonora. México

Dr. Juan Flores Preciado

Universidad de Colima. México

Dr. Amado Olivares Leal. Universidad de Sonora

Universidad de Sonora. México

Dr. Guillermo Velázquez Valadez.

Instituto Politécnico Nacional (IPN) México

Dr. Hugo Nefstalí Padilla Torres.

Universidad Estatal de Sonora. México

Dr. Luis Ramón Moreno Moreno.

Universidad Autónoma de Baja California. México 
Año 13.

Revista de Investigación

Núm. 33

Académica sin Frontera

https://revistainvestigacionacademicasinfrontera.unison.mx/index.php/RDIASF

Recibido el 14 de abril de 2020. Dictaminado mediante arbitraje favorablemente 9 de julio de 2020

Dr. Miguel Ángel Vázquez Ruiz.

Universidad de Sonora. México

Dra. Lorena Vélez García.

Universidad Autónoma de Baja California. México

Dra. Pabla Peralta Miranda.

Universidad Simón Bolívar, Barranquilla, Colombia

Mtro. Roberto Espíritu Olmos

Universidad de Colima (FCA Tecomán) Colima

Dr. Héctor Priego Huertas.

Universidad de Colima (FCA Tecomán) Colima

Mtra. María Guadalupe Alvarado Ibarra.

Universidad de Sonora. México.

MSc. Celso Germán Sánchez Zayas

Universidad de Camagüey, Ignacio Agramonte Loynaz, Cuba

Dra. María Luisa Quintero Soto

Universidad Autónoma del Estado de México

Dr. Eyder Bolivar Mojica

Universidad Católica, Luis Amigó, Medellin, Colombia

Revisores de Textos en Inglés

Mtro. Renato Encinas

Mtra. Cecilia Guadalupe Martínez Solano

\section{Comité científico}

Dr. Rosendo Martínez Jiménez. Universidad Autónoma Benito Juárez de Oaxaca.

Dr. Hugo Neftalí Padilla. Universidad Estatal de Sonora

Dra. María Teresa Gaxiola Sánchez. Universidad de Sonora.

Dr. José Cesar Kaplan. Universidad Estatal de Sonora.

Dr. Alfredo Islas Rodríguez. Universidad de Sonora

Frecuencia de publicación: semestral / 2 números por año. 
Año 13.

Revista de Investigación

Núm. 33

Académica sin Frontera

ISSN: 2007-8870

https://revistainvestigacionacademicasinfrontera.unison.mx/index.php/RDIASF

Recibido el 14 de abril de 2020. Dictaminado mediante arbitraje favorablemente 9 de julio de 2020

Revista de Investigación Académica sin Frontera (RIASF) con (ISSN: 2007-8870) es un interlocutor internacional de acceso abierto revisado diario en línea en el ámbito del de las Ciencias Económicas Administrativas y Sociales. Su objetivo principal es dar a los trabajos de investigación de calidad. Cubre todas las sub-campos de los campos anteriormente mencionados. Proporciona la plataforma a académicos, estudiantes y profesionales. Sólo pública trabajos de investigación y artículos de revisión inicial. Documento presentado debe cumplir con algunos criterios como, debe ser original, inédita y no estén sometidos a ninguna otra revista.

RIASF es una revista arbitrada / Revisión por pares International. Publicamos documentos sobre una variedad de temas, contextos y estrategias de análisis que examinan la relación entre la rápida evolución para la Sociedad y la tecnología del conocimiento.

REVISTA DE INVESTIGACIÓN ACADÉMICA SIN FRONTERA, Año 13, No. 33, Julio - diciembre 2020, es una publicación semestral de investigación científica, editada por la Universidad de Sonora, a través de las División de Ciencias Económicas y Sociales, de la Unidad Regional Sur, Blvd. Lázaro Cárdenas No. 100, Col. Francisco Villa, Navojoa, Sonora, Sonora, México, C.P. 85880. Tel. (642) 42599-54.

http://www.revistainvestigacionacademicasinfrontera.com/, revistaacademicasinfrontera@ unison.mx. Editor responsable: Francisco Espinoza Morales. Reserva de Derechos al Uso Exclusivo: 042013-121811323700-203 e ISSN: 2007-8870, ambos otorgados por el Instituto Nacional de Derecho de Autor. Inscrita en el Directorio de LATINDEX, con Núm. De folio 20014, folio único 14590. Responsable de la última actualización de este Número, Unidad Informática de la Universidad de Sonora, fecha de la última modificación, 30 de diciembre 2020, indexada a Cite Factor Academic Scientific Journal y Journals Master (IIJIF) y Red Latinoamericana de Revistas Académicas en Ciencias Sociales y Humanidades, (Latín Rev). Las opiniones expresadas por los autores no necesariamente reflejan la postura del editor de la publicación. Se autoriza la reproducción total o parcial de los contenidos e imágenes en la presente publicación siempre y cuando se cuente con la autorización del editor y se cite plenamente la fuente. 
Nos complace anunciar que su diario, "Academic Research Journal Withoutborders" (ISSN/EISSN 2007-8870) fue evaluado positivamente en la indexación Citefactor, ahora la página de la revista está disponible en línea, en caso de cualquier problema.

Journals Master | International Innovative Journal Impact Factor (IIJIF)

\section{Red Latinoamericana de revistas Académicas en Ciencias Sociales y Humanidades}
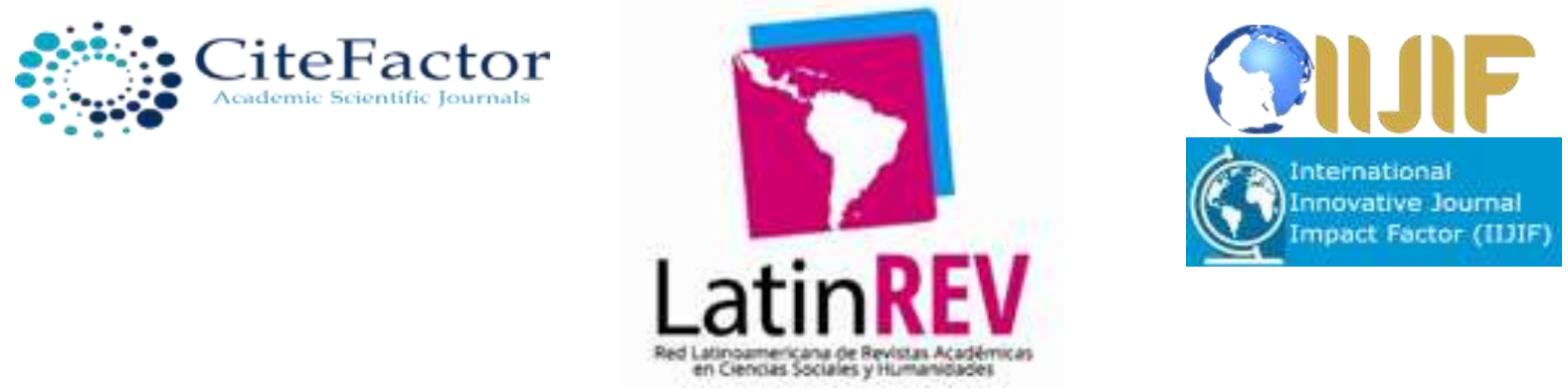

https://www.neliti.com

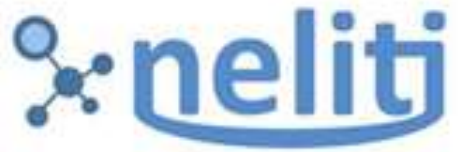

Indonesia's Research Repository
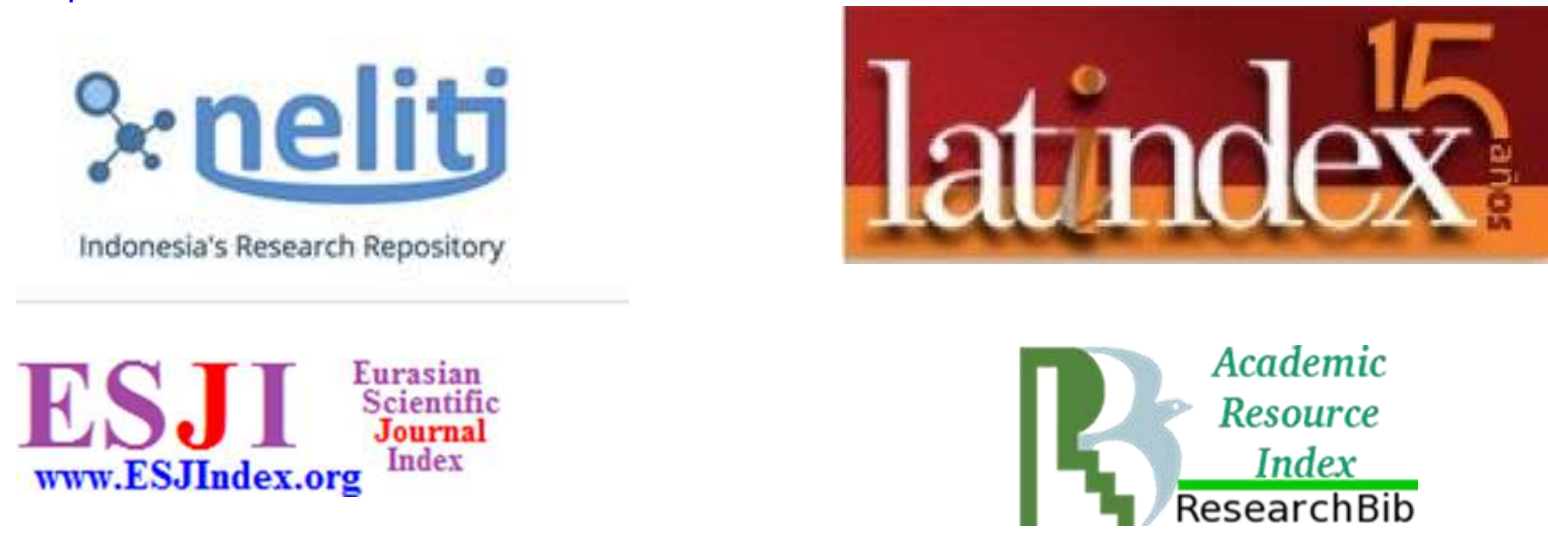